\title{
Degemination in Hungarian: phonology or phonetics?
}

\author{
Péter Siptár \\ Eötvös Loránd University, Budapest, and \\ Research Institute for Linguistics, \\ Hungarian Academy of Sciences \\ siptar.peter@nytud.mta.hu
}

\author{
Tekla Etelka Gráczi \\ Research Institute for Linguistics, \\ Hungarian Academy of Sciences \\ graczi.tekla.etelka@nytud.mta.hu
}

\begin{abstract}
It is traditionally held with respect to Hungarian degemination that geminates do not occur in this language word initially or flanked by another consonant on either side. The occurrence of geminates, true and fake ones alike, is said to be impossible except intervocalically or utterance finally (if preceded by a vowel and followed by a pause). However, this traditional view is oversimplified. Siptár (2000) proposed to amend it by positing three different degemination rules, applying at word level, postlexically, and in the phonetic implementation module, respectively. Furthermore, he reinterpreted several cases that traditionally had been analysed as degemination as lack of gemination. In view of the recent literature, however, the hypothesis can be advanced that the whole issue should be seen as a matter of phonetic duration rather than that of phonological quantity. In particular, the hypothesis is that the familiar degemination effects are not specific to geminates: they are due to phonetic compression of CCC clusters. The paper presents and discusses that hypothesis and cites some results of a small-scale phonetic experiment designed to confirm (or disconfirm) it by empirical data. Six short texts involving all types of geminates and control sequences with both short and long consonants were created. Six consonants (two fricatives, three plosives, and a nasal) were used in the test (and control) sequences. The duration of the target consonant and that of the consonant cluster including it were measured in each case. The results partially support the hypothesis but they also raise some further questions.
\end{abstract}

Keywords: true geminates, fake geminates, degemination, phonetic compression, autosegmental representation

\section{Introduction}

The traditional insight concerning the surface distribution of geminates in Hungarian is that they never occur (i) word initially, or (ii) flanked by another consonant on either side. ${ }^{1}$ In other words, the occurrence of geminates is only possible (i) intervocalically (e.g. állat 'animal', áll-at 'chin-acc', áll Attila 'Attila stands') and (ii) utterance finally (i.e., before a pause) if preceded by a vowel (e.g. áll 'stand'/'chin'). The latter type is, however, degeminated if a consonant follows, irrespective of whether that consonant comes from synthetic suffixation (e.g. áll-t 'stand' (3sg past), áll-tam 'stand' (1sg past)), analytic suffixation (e.g. áll-hat 'may stand'), compounding (áll-támasz 'chin rest') or even from a different word (áll Tamás 'Tom stands'). However, this traditional view is oversimplified and has to be revised, to be at least observationally adequate, in various ways. ${ }^{2}$ This revision, as

\footnotetext{
1 On the small overall functional load of geminate consonants in Hungarian, see Obendorfer (1975). On geminates and gemination in general, see Delattre (1971), Lehiste et al. (1973), Pickett et al. (1999), Ham (2001), Ringen \& Vago (2011), Oh \& Redford (2012), as well as Davis (2011) and further literature cited there. On various aspects of (and approaches to) degemination in Hungarian, see also Nádasdy (1989), Dressler \& Siptár (1989), Siptár \& Törkenczy (2000), and Polgárdi (2008).

2 A point of minor significance concerns the examples in this paragraph rather than the issue of degemination. In a number of lexical items there is free variation between short and geminate consonants; one of the most characteristic combinations where this holds is /a:/ followed by /1:/ as in áll 'chin', áll 'stand', állam 'state', állat 'animal', állomás 'station', istálló 'stable', szakáll 'beard', száll 'fly' (verb), váll 'shoulder', vállal 'undertake',
} 
well as an analysis, both in phonetic and in phonological terms, of the issue of degemination, is the topic of the present paper.

In a detailed study of degemination in Hungarian, Nádasdy (1989) distinguished underlying vs. derived geminates and left-flanked vs. right-flanked ones. Within the class of derived geminates he further distinguished true (assimilation-based) vs. fake (juxtaposition-based) geminates. The former type involves linked structure as in lábbal 'with leg' (its representation is identical with that of underlying geminates, cf. (1a)) and the latter type involves a sequence of identical short consonants across an analytic morpheme boundary as in lábban 'in leg' (cf. (1b)); the surface shape (actual phonetic implementation) of such sequences, however, is normally indistinguishable from that of true geminates.

(1) a. True geminate

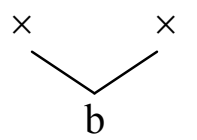

b. Fake geminate

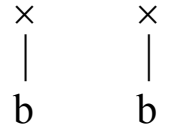

c. Singleton

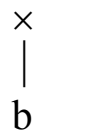

Siptár (2000) accounted for the issue of degemination in Hungarian in a paper that was based on Nádasdy's data and classifications but where the actual analysis differed from his in some respects: in essence, four distinct areas were defined within the range of phenomena pertaining to degemination. With respect to the first, it was claimed that some of the cases that had traditionally been analysed as degemination should be reinterpreted as lack of gemination. For the other three sets of cases three different degemination rules were proposed, applying at word level, postlexically, and in the phonetic implementation module, respectively. In view of the recent literature and due to some further considerations, however, the hypothesis can now be advanced that the whole issue should perhaps be seen in an entirely different light: as a matter of phonetic duration rather than that of phonological quantity.

The present paper will be organised as follows. In the rest of the present section, some major claims of Siptár (2000) will be briefly reviewed. Then, in Sections 2 and 3, a programmatic sketch of the new hypothesis will be provided, with some motivation of why it appears to be a promising idea in the first place. In Sections 4 and 5 we cite some results of a small-scale phonetic experiment designed to confirm (or disconfirm) the hypothesis by empirical data. Section 6 summarises our findings and Section 7 concludes.

\subsection{Underlying geminates}

Right-flanked underlying geminates behave roughly in the way described above, except that across a word boundary degemination is optional and varies in terms of speech style and boundary strength (cf. Dressler \& Siptár 1989): the "stronger" the boundary and/or the more formal the register, degemination is the less likely to apply. (We will return to a brief discussion of this type in 1.2 below.)

Left-flanked underlying geminates do not normally occur since no morpheme begins with a geminate consonant. There are two possible candidates for morphemes consisting of a geminate consonant: comparative $-b b$ and past tense $-t t .^{3}$ The former hardly ever occurs in a

vállalat 'company', etc. This very surfacy (but, for very many speakers, practically exceptionless) type of shortening will be ignored in what follows.

3 The geminate exponent of the past tense morpheme only occurs after vowels; hence, it is outside the (leftflanked) degemination context. However, already since Vago (1980), it is not à la mode to account for the $-t \sim-t t$ alternation of the past tense morpheme in terms of allomorph selection (although counterexamples do occasionally turn up, e.g. Stiebels \& Wunderlich 1999). Now if we wish to attribute a single underlying shape to this morpheme, and assume that it is based on the - $t$ t surface alternant, the most straightforward way to derive the 
degemination context; it is a Type A suffix ${ }^{4}$ (e.g. nagy-obb 'bigger', csúnyá-bb 'uglier') that, however, exceptionally 'loses' its unstable vowel in a handful of lexicalized forms: különb 'superior', idösb 'elder', and nemesb 'nobler'; also in some forms containing the verbalizing suffix -it: helyesbit 'rectify', öregbit 'enhance', súlyosbit 'aggravate'. With respect to the past tense suffix, Siptár \& Törkenczy (2000, 244-256) suggest that it exhibits degemination effects without actually undergoing degemination. In particular, they suggest that this suffix is a $/ \mathrm{t} /$ whose root node is underlyingly associated to a single timing slot followed by an empty timing slot, i.e. a timing slot devoid of melodic content (see (2a)). They further assume that a rule of $t$-spread applies to this configuration if a full vowel precedes (see $(2 \mathrm{~b}$ ), where $\mathrm{V}$ stands for a full (nonempty) vowel).

(2) a.

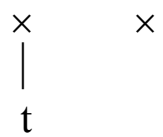

b.<smiles>[Y][Te]O</smiles>

/ V

Thus, in a form like fal-t 'devoured (3sg past)', a geminate never occurs in the first place, hence there is nothing to degeminate. ${ }^{5}$ On the other hand, in cases like lát-ott 'see (3sg past)', ad-ott 'give (3sg past)', rule (2b) applies and creates a derived true geminate. ${ }^{6}$

\subsection{Derived true geminates}

Another type of suffix showing degemination effects without actually undergoing degemination is the set of "alternating $v$-suffixes" whose initial consonant copies the stemfinal consonant, if any, and otherwise surfaces as [v] (instrumental-val/vel: só-val 'with salt', méz-zel 'with honey', and translative -vá/vé: só-vá '(turn) into salt', méz-zé '(turn) into honey'). ${ }^{7}$ This case (if it did involve degemination) would be that of a left-flanked derived

$-t$ alternant from it would be a degemination-based analysis. For more details on the past tense morphology of Hungarian, a rather complex issue in its own right, see Trón \& Rebrus (2005) and the literature cited there.

4 Siptár \& Törkenczy (2000) distinguish two types of unstable-vowel-initial suffixes (in traditional terms, suffixes requiring a linking vowel in some contexts). Type A includes suffixes (like plural $-k$ ) whose initial unstable vowel is only unrealised when they are added to a vowel-final stem; a phonetically realised vowel is always present after a consonant-final stem, regardless of the identity of the stem-final consonant. Type B, on the other hand, whose typical instance is accusative $-t$, exhibits phonotactically motivated vowel $\sim$ zero alternation, i.e. the unstable vowel is phonetically unrealised iff the suffixal consonant can syllabify as (part of) a wellformed coda. This means that no linking vowel appears after vowels and after stem-final consonants with which the suffixal consonant can form a branching coda. See Siptár \& Törkenczy (2000, 219-224) for details.

\footnotetext{
5 The empty $\times$, unable to receive melody from the spreading of the $t$ after a consonant, will remain inaccessible
} for phonetic implementation, and is therefore not represented by anything in the surface pronunciation.

${ }^{6}$ When such a form is followed by a consonant-initial word, a case of right-flanked derived true geminate arises and what happens is the same as in other similar cases, cf. rule (5) further below.

7 There are "non-alternating $v$-suffixes" as well (such as -van/ven '-ty': hat-van 'sixty', deverbal noun-forming vány/vény: lát-vány 'sight', deverbal adverb-forming -va/ve: lop-va 'stealthily') which are likewise [v]-initial after vowel-final stems, but whose initial /v/ remains unchanged even after consonant-final stems. The two types of suffixes can be represented as follows:
(i) - val/vel: $\quad \times$
$\left.\left.\right|_{A} ^{\times} \quad\right|^{\times}$
(ii) $-v a / v e$ :
$\begin{array}{ll}\times & \times \\ v & A\end{array}$

If - val/vel is added to a vowel-final stem, its empty slot is filled in by $v$; if it is added to a stem ending in a single consonant, the spreading rule in (3) applies; and finally, if it is added to a cluster-final stem, nothing happens and the empty $\times$ remains empty. (This would be the most straightforward account of the dissimilar behaviour of the two types of $v$-initial suffixes. Note that the solution offered by Siptár \& Törkenczy (2000) is not exactly this, 
true geminate: domb-bal [mb] $(*[\mathrm{mb}:])$ 'with hill', vers-sel $\left[\mathrm{r} \int\right]\left(*\left[\mathrm{r} \int:\right]\right)$ 'with poem', lánc-cá [nts] (*[nts:]), '(turn) into chain', férj-jé [rj] (*[rj:]) '(turn) into husband'. The analysis Siptár and Törkenczy offer for this case involves the generalisation of $t$-spread into a rule of ' $\mathrm{C}$ spread' (see (3)) that applies in e.g. méz-zel 'with honey', etc. but not in domb-bal 'with hill', etc., giving the desired degemination effect.

\section{(3) C-spread}

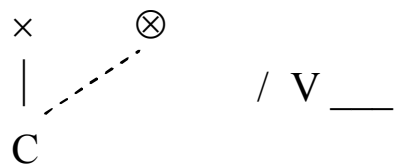

Siptár (2000) accounted for several further cases of (apparent) degemination in a similar vein, that is, in terms of the failure (restriction) of gemination. ${ }^{8}$ However, there is at least one further type of case that can by no means be analysed without a degemination rule. The output of voice assimilation ${ }^{9}$ may or may not come out as a geminate (it does if the two segments only differed in terms of voicing, e.g. adta [ot:o]; it does not otherwise, e.g. dobta [dopto]). The merger of all class nodes dominating identical material that is involved here is an automatic OCP-effect (cf. Leben 1973; Clements 1985), not a rule - hence we cannot manipulate it in a way similar to what we did above (i.e., we cannot factor out the spreading part from a spreading-cum-delinking complex and constrain it in terms of left context). Thus, we need a degemination rule for cases like küldte [kylte] 'he sent it': /ldt/ $\rightarrow$ lt: $\rightarrow$ [lt]. That rule can be informally stated as in (4):

\section{(4) Degemination I}

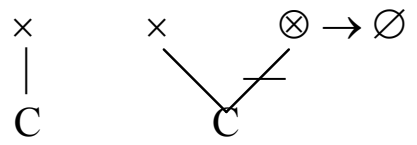

Rule (4) is a lexical (word level) rule, meaning that it only applies within words but it is strictly obligatory there. Apparently, something similar happens in cases like küld tehát 'sends therefore' or volt dolga 'had something to do', that is, in cases where a derived geminate that comes about by voicing assimilation straddles a word boundary. However, this latter type of degemination is, on the one hand, optional, and on the other hand, gradual (that is, not one of the yes/no type but of the more/less type). In addition, it is sensitive to the quality of the flanking consonants (its application is more likely, and its effect is more radical, if the flanking consonant is an obstruent as in hozd tehát 'bring it therefore!' than if it is a liquid as in hord tehát 'carries therefore'). That is, this type behaves quite similarly to fake geminates (see section 1.3 below; cf. also Oh \& Redford (2012) on fake geminates in English).

Turning to right-flanked derived true geminates as in $\ddot{u} s$ /yt-j-d/ [yzd] 'hit' (2sg imp. def.), Siptár (2000) suggests that we need a mirror image of (4) to handle right-flanked

but for our present purposes this simplified account will do.) A totally different analysis of this phenomenon is given by Pycha $(2008,88-95)$.

\footnotetext{
8 Such cases include (i) imperatives of sibilant-final verbs like rajzzon /rajz-j-on/ $\rightarrow$ [rojzon] 'swarm' (3sg imp.), and (ii) verb forms, both indicative and imperative ones, involving palatal coalescence as in tart-ja [torco] 'hold' (3sg ind. def.), hord-ja [horı] 'carry' (3sg ind./imp. def.).

9 This problem is by no means particular to voice assimilation. It arises in all cases where a spreading operation involving a single feature or a single class node leads to complete identity (hence to a derived true geminate) by accident, as it were.
} 
underlying geminates as in hall-gat [holgot] 'listen', as well as the kind of right-flanked derived true geminates (e.g. hallott felöle [hol:otfelø:le] '(s)he has heard about it') mentioned in footnote 6 above. Therefore, we formulate the following rule for all right-flanked true geminates, whether underlying or derived (see (5)).

\section{(5) Degemination II}

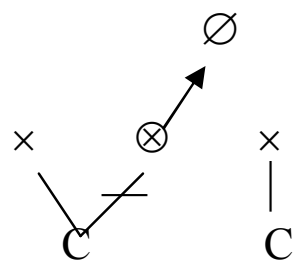

The question arises at this point whether it would be a good idea to collapse (4) and (5) into a mirror-image formula ("Delink and delete one $\times$ of a true geminate if another consonant precedes or follows"). The answer is that it would not be a good idea: (4) applies strictly word internally and is obligatory, whereas (5) optionally applies in the postlexical component of the grammar ${ }^{10}$ and its probability of application covaries with speech rate and (inversely with) boundary strength (Dressler \& Siptár 1989).

\subsection{Fake geminates}

Finally, consider fake geminates (i.e. sequences of identical consonants arising across analytic morpheme boundaries). Note first of all that - with the possible exception of geminate affricates as in kulcscsomó 'bunch of keys' and unlike geminate vowels as in kiirt 'exterminate' - fake geminate consonants surface phonetically as if they were true geminates. This means that at some point they will undergo merger (one which is either OCP-driven or rulebased, depending on one's general assumptions). That merger can take place either too early or too late: if it takes place before (postlexical) degemination is considered for application, the difference between the behaviour of true and fake geminates may become inexpressible; if, on the other hand, merger is later than degemination, it may be difficult to refer to adjacent identical consonants that do not form a linked structure (coindexing is one possibility but not a very pleasant one).

Consider the following data (partly based on Nádasdy (1989); '-' stands for morpheme boundary and '\#' stands for compound boundary):

(6) a. Left-flanked fake geminates:

"Obligatory" degemination if the flanking consonant is an obstruent:

$\begin{array}{lllr}\text { koszt-tól } & {[\text { kostol }]} & \text { 'from food' } & \text { (analytic suffix) } \\ \text { direkt\#termő } & {[\text { dircktcrmö:] }} & \text { 'a type of vine' } & \text { (compound) } \\ \text { lakj jól } & {[\text { lokjo:1] }} & \text { 'eat enough' (2sg imp.) } & \text { (phrase) }\end{array}$

"Optional" degemination if the flanking consonant is a nasal:

$\begin{array}{llr}\text { comb-ból } & \text { [tomb(:)ol] 'from thigh' } & \text { (analytic suffix) } \\ \text { csont\#tányér } & {[\text { tont(:)a:je:r] 'bone plate' }} & \text { (compound) } \\ \text { tank körül } & \text { [tonk(:)øryl] 'around tank' } & \text { (phrase) }\end{array}$

\footnotetext{
10 This is independently demonstrated by the fact that it applies across a word boundary, too; a rule of the lexical module of phonology would be unable to do that.
} 
"No degemination" if the flanking consonant is a liquid:

$\begin{array}{lllr}\text { sztrájk-kor } & \text { [strajk:or] } & \text { 'during a strike' } & \text { (analytic suffix) } \\ \text { talp\#pont } & \text { [tolp:ont] } & \text { 'foot-end' } & \text { (compound) } \\ \text { szerb bor } & \text { [scrb:or] } & \text { 'Serbian wine' } & \text { (phrase) }\end{array}$

b. Right-flanked fake geminates:

"Obligatory" degemination if the flanking consonant is an obstruent:

$\begin{array}{lllr}\text { kis\#stílu } & {[\text { kifti:ly] }} & \text { 'petty' } & \text { (compound) } \\ \text { olasz sztár } & \text { [olosta:r] } & \text { 'Italian (film) star' } & \text { (phrase) }\end{array}$

"Optional" degemination if the flanking consonant is a nasal:

$\begin{array}{lllr}\text { ös\#smink } & {\left[\varnothing: \int(:) \operatorname{mink}\right]} & \text { 'proto-make-up' } & \text { (compound) } \\ \text { kész sznob } & {[\mathrm{ke}: \mathbf{s}(:) \mathrm{nob}]} & \text { 'a perfect snob' } & \text { (phrase) }\end{array}$

"No degemination" if the flanking consonant is a liquid:

$\begin{array}{lllr}\text { szép\#próza } & \text { [se:p:ro:zo] } & \text { 'prose fiction' } & \text { (compound) } \\ \text { ügyes srác } & \text { [yłєf:ra:ts] } & \text { 'smart boy' } & \text { (phrase) }\end{array}$

The terms "obligatory", "optional", and "no degemination" appear in quotation marks in (6) since it appears that there is a continuous gradient of optionality here in which "most likely", "less likely" and "least likely", respectively, would be more appropriate labels. The type of degemination we are considering is simply an optional process whose likelihood covaries with the type of the flanking consonant as indicated. What is more, it is not merely the probability of the application of this process that is variable but also the degree of shortening involved: in other words, the phenomenon can only very roughly and inaccurately be described categorically, in terms of the singleton/geminate (or short/long) opposition; this, then, is not a matter of quantity but that of duration (in the strict sense of both those terms).

The question is whether the phenomenon displayed in (6) is due to a postlexical phonological process or rather part of phonetic interpretation. An argument that supports the latter option is that the merger of fake geminates into true ones is most probably a phonetic issue and - unless we want to formulate a deletion rule referring to (coindexed) identical segments ${ }^{11}$ - the earliest point where this simplification process can be stated in terms of linked structures is after that merger has taken place. Therefore, Siptár (2000) offers the following two statements as part of the phonetic implementation module of the grammar of Hungarian:

\section{(7) a. Long Consonant Formation}

Merge a sequence of two identical short consonants into a single long consonant (applies in all speech styles/tempos with respect to consonants other than affricates; applies to affricates in fast/casual speech only)

b. Degemination III

Optionally realize a long consonant as short if it is flanked by another consonant (applies with decreasing likelihood when the flanking consonant is (i) an obstruent, (ii) a nasal, or (iii) a liquid)

\footnotetext{
11 For one thing, we cannot do that because, if we did, we would have to give up all reasonable hope of being able to account for the gradual character of the phenomenon.
} 
Note that ( $7 \mathrm{~b}$ ) does not mention anything about being restricted to (merged) fake geminates. This is as intended: all long consonants that go back to true geminates but fail to have been affected by either of the other two rules of degemination ${ }^{12}$ are free to serve as further input to this phonetic process of shortening.

\subsection{Summary}

In this section, we have reviewed Siptár (2000)'s three different degemination rules, applying at word level, postlexically, and in the phonetic implementation module, respectively. (4) is the word level rule that applies obligatorily to all left-flanked true geminates that emerge from the lexical phonology as such, irrespective of the identity of the flanking consonant and of the morphological make-up (underlying vs. derived) of the geminate itself. Instances of this process are cases like önts [ønt'] 'pour' (2sg imp. indef.), ${ }^{13}$ hordtam [hortom] 'carry' (1sg past def.) where degemination is directly fed by palatalisation in the first example and by voice assimilation in the second. ${ }^{14}$

The postlexical rule is (5) that applies obligatorily within words and optionally in phrasal domains (with decreasing likelihood across increasingly "stronger" syntactic boundaries and in increasingly formal speech styles). However, the rule is insensitive to the identity of the flanking consonant and to whether the geminate is underlying or derived. Instances of this process include hallgat [holgot] 'listen', üsd /yt-j-d/ [yzd] 'hit' (2sg imp. def.), adj neki [oyncki] 'give him', evett banánt [Evedbona:nt] 'he ate some bananas'.

Finally, the phonetic rule is ( $7 \mathrm{~b})$ that applies optionally and targets - primarily but not exclusively - long consonants that are (phonologically) fake geminates. The gradience of optionality is as stated in (7b); examples appear in (6) above.

\section{The duration and internal structure of geminates (and degemination)}

Both the traditional account and Siptár (2000)'s reanalysis tacitly assumed two simplifications of the data: first, they took geminates to be phonologically (metrically, rhythmically) equivalent to clusters of two dissimilar consonants and/or "twice as much as" singleton consonants (that is, they pretended that long consonants are practically twice as long as the corresponding short consonants are); and second, they ignored the familiar phonetic fact that the internal time structure of geminates is not necessarily the same as that of the corresponding single consonants (that is, the fact that the internal timing of consonants with a complex pattern of articulation may differ depending on whether they are short or geminate).

The usual autosegmental representations of both true and fake geminates as in (1) above, as well as the term geminate itself, seem to suggest that the durations of short vs. long consonants have a rough proportion of $1: 2$. But, as in many other languages, this is far from

\footnotetext{
12 In the case of left-flanked true geminates this means all instances that straddle a word boundary as in kezd tehát 'begins therefore' (see above); from among right-flanked true geminates, it covers the ones that have survived (5) unscathed due to its optionality.

13 Note that cases like öntse [ønt $f \varepsilon]$ 'pour' (3sg imp. def.) and öntsd [øndzd] [ønzd] [ø̃:zd] 'pour' (2sg imp. def.) also belong here, i.e. it does not matter whether the geminate is followed by nothing, a vowel, or a consonant; what is important is the left-hand consonant, $n$ in this case, that is the necessary and sufficient condition for degemination to apply.

14 Recall that a number of cases that are traditionally analysed as degemination are reinterpreted in Siptár (2000) as lack of gemination. The major cases include (i) past-tense verb forms like kap-t-a 'get' (3sg past def.) and fal-t 'devour' (3sg past indef.), (ii) noun forms involving "alternating $v$-suffixes" like domb-bal [dombol] 'hill' (instr.), see also footnote 8 above.
} 
being the case. ${ }^{15}$ For instance, Olaszy $(2006,79)$ found that the average duration of all consonants in a read corpus of 12,364 speech sounds, with 13 sounds/s speech rate, was $68.6 \mathrm{~ms}$, while that of all short consonants was almost exactly the same: $67.4 \mathrm{~ms}$. Of course, this primarily reflects the fact that his material contained far more singletons $(6,925)$ than geminates (273). As another passage of his monograph reveals, the average duration of the long consonants of his corpus was $109.1 \mathrm{~ms}$, that is, $162 \%$ of the average duration of the short consonants. Such average values conceal a number of individual differences, though. First, specific durations of the individual consonant types differ widely (Olaszy 2006, 81-82), and a number of other factors also affect the actual duration of a consonant in a given position (for instance, the phrase final position is a length increasing factor). In Olaszy's material, the shortest short consonant was $8 \mathrm{~ms}$ long, ${ }^{16}$ while the longest long consonant took $251 \mathrm{~ms}$. What is even more of a surprise perhaps: the longest "short" consonant was even longer: $261 \mathrm{~ms} .{ }^{17}$ Interesting observations can also be made if we look at individual short/long pairs. For instance, the longest singleton $/ \mathrm{b} /$ was $120 \mathrm{~ms}$, while the shortest geminate $/ \mathrm{b}: /$ was roughly half that much: $63 \mathrm{~ms}$. The average values were $58 \mathrm{~ms}$ and $83 \mathrm{~ms}$, respectively, that is, the duration of geminate /b:/'s was $143 \%$ of that of singleton /b/'s on average.

These data concern read speech and might therefore show the effect of written forms. ${ }^{18}$ According to Beke \& Gyarmathy (2010)'s data measured in a spontaneous speech sample of 11,000 speech sounds, the mean duration of singleton/s/'s was $91 \mathrm{~ms}$ (SD $33 \mathrm{~ms}$ ), and that of geminate /s:/'s was $120 \mathrm{~ms}$ (SD $57 \mathrm{~ms}$ ); the ratio, then, was as small as $131 \%$. The shortest tokens were practically the same length in both categories - and the wider scatter of long tokens was towards smaller values.

However, geminates (in particular, geminate plosives and affricates) do not only differ from corresponding singletons in their overall duration but also in their internal structure. Unlike singletons that are phonetically lengthened e.g. phrase finally before a pause, geminates exhibit a lengthened medial portion, i.e., in plosives/affricates, a lengthened closure phase. ${ }^{19}$ In the case of such complex consonants, especially in that of affricates, any

${ }^{15}$ An anonymous reviewer notes that "it is unclear why the phonological length contrast should correlate with (absolute) phonetic duration values. Phonological representation should simply encode that two segments categorically differ with respect to length, not more; and for that purpose, a representationally simplified model (like the autosegmental one in (1a)) is quite enough; the fact that the actual proportion of phonetic durations is not $1: 2$, is irrelevant phonologically. The question is whether a phonological representation that reflects phonetic length relations more faithfully has any phonological relevance". It would be inappropriate, in terms of space considerations and also in general, to dwell on this issue at length here; let us just note that, for instance, Articulatory Phonology (e.g. Browman \& Goldstein 1992) or, more recently, Resizing Theory (Pycha 2008) is based on that particular idea: they deny the relevance of temporal "slots" in the phonological representation of length.

Furthermore: in the eighties and nineties, various authors, teams of researchers, and research projects set themselves the aim of dispelling not only rules and derivations, but even phonological segments themselves from their phonological accounts; see e.g. Local (1992) and the literature cited there. And in the early two thousands, an increasing number of authors insist that formal linguistics, especially phonological theory, should be given a real-time character. They claim that "rich behavioral details are essential to describe linguistic behavior - in word recognition processes, in the gestures of speech articulation, for speech memory and so forth", concluding that linguistics "cannot stand by and deny the relevance of continuous time if it is to seriously address aspects of human cognition" (Port \& Leary 2005, 958).

$16[\mathrm{r}]$ in the expression legjobb tudomásom szerint 'to the best of my knowledge'.

17 [s] at the end of the sentence Gyere be nyugodtan, nem zavarsz 'Do come in, you are not disturbing me'.

18 Of course, such an effect, if there was one, will have counteracted the tendencies reported: that is, it may have pointed towards a longer pronunciation of long consonants and a shorter rendering of short ones.

19 In fricatives and sonorants, the various portions of the segment do not differ in any relevant manner from one another, hence the difference in timing referred to here is either nonexistent or impossible to detect. For more 
lengthening process may have two targets, rather than one: the closure phase and the frication phase. It is, then, possible in principle that phonetic and phonological lengthening processes affect such targets differentially.

Pycha (2009) studied the phonetic lengthening and gemination of Hungarian voiceless affricates in this respect and found that phrase final lengthening increases the mean duration of phrase final singleton affricates to $179 \mathrm{~ms}$ (SD $35.7 \mathrm{~ms}$ ) as opposed to the $107 \mathrm{~ms}$ (SD 20.6 ms) of phrase internal singleton affricates, that is, she found a ratio of $167 \%$ (and wider standard deviation). As to internal proportions: the mean duration of closure phases of phrase internal affricates was $37.6 \mathrm{~ms}$, and those of phrase final affricates were $62.1 \mathrm{~ms}$ long $(165 \%)$, while the corresponding frication phases were $69.5 \mathrm{~ms}$ and $117 \mathrm{~ms}$, respectively $(168 \%)$. These results can be interpreted in two different ways. The ratio between closure phases and frication phases remained practically constant, that is, their internal structure did not change during the lengthening process. However, looking at the absolute values, we find that the frication phases undergo lengthening to a far larger extent, by $47.5 \mathrm{~ms}$, as opposed to the 24.5 ms lengthening of the closure phase. This might suggest a kind of "locality" hypothesis: in phonetic lengthening, the part of affricates that is primarily affected is the one that is closer to the phrase boundary (the trigger of the process). The latter interpretation is supported by the fact that the total increase of duration more closely correlates with the increase of the frication phase than with that of the closure phase. ${ }^{20}$ Pycha came to the conclusion that in the case of phonetic lengthening the primary target is the portion that lies closer to the trigger of the process, while the other portion is but a secondary target.

With respect to the phonological lengthening (gemination) triggered by -val/-vel 'with', Pycha (2009) found the following results. As expected, when she compared the total duration of affricates in forms in -on/-en/-ön 'on' (e.g. teknöcön 'on a tortoise') with that in forms in -val/-vel (e.g. teknöccel 'with a tortoise'), she got $149.3 \mathrm{~ms}$ (SD $29.9 \mathrm{~ms}$ ) for the former and $223.6 \mathrm{~ms}$ (SD $32.8 \mathrm{~ms}$ ) for the latter, that is, a ratio of $150 \%$. More to the point, the closure phase of affricates preceding a plain (non-geminating) suffix was $59 \mathrm{~ms}$ (SD 17.6 $\mathrm{ms}$ ), and preceding a geminating suffix it was $123.8 \mathrm{~ms}$ (SD $40.7 \mathrm{~ms}$ ), the ratio being $210 \%$. On the other hand, the frication phase exhibited a minimal amount of lengthening: $90 \mathrm{~ms}$ (SD $17 \mathrm{~ms}$ ) vs. $100 \mathrm{~ms}$ (SD $25 \mathrm{~ms}$ ), with a ratio of $111 \%$. In other words, before -val/-vel, the closure phases of affricates became more than twice as long while the frication phases remained almost the same length. That is, in the case of phonological lengthening (gemination), the primary target of lengthening is the closure phase of affricates, and the frication phase is but a secondary target.

Against the backdrop of the foregoing data, consider what happens in degemination contexts, that is, in cases like kinccsel 'with treasure', tánccal 'with dance'. According to the measurements of Pycha (2010), in cases like ráccsal 'with grating', páccal 'with brine', the full duration of affricates is $150 \%$ of the corresponding singleton affricates $(223.6 \mathrm{~ms}$ vs. $149.3 \mathrm{~ms})$, whereas in cases like kinccsel, tánccal it is $110 \%(149.1 \mathrm{~ms} v \mathrm{vs} .135 .5 \mathrm{~ms}) .{ }^{21}$ That

details on the internal timing of Hungarian affricates see Kovács (2002). - The issue of internal timing in the various realisations of $/ \mathrm{r} /$ is quite independent and cannot be discussed here; see Gósy (2008) and the literature cited there.

20 Pycha studied phrase initial lengthening, too, and found that in that case, just the other way round, the total increase of duration more closely correlated with the increase of the closure phase than with that of the frication phase.

21 An anonymous reviewer has pointed out to us that the mean duration of intervocalic singleton affricates (rácson 'on grating') and left-flanked geminate affricates (kinccsel 'with treasure') exactly coincide in the data cited here (149 ms). However, this is a misleading coincidence: it does not prove that the latter necessarily shows degemination effects, given that all consonants tend to be shorter in a consonant cluster than in an intervocalic position. A categorical (and indubitable) degemination effect would be attested if the affricates in kincsem 'my treasure' and kinccsel 'with treasure' turned out to be of identical duration. 
is, in unrestricted cases, the geminate is one and a half times (rather than twice) as long as the corresponding singleton (in harmony with the results of Pycha (2009) and also with the results of Olaszy (2006) and Beke \& Gyarmathy (2010) cited above, but in contrast with the conventional naive wisdom); but, more surprisingly, in the degemination cases, the geminate does not become as short as the singleton, or taking a different perspective: the flanking consonant does not prevent the gemination of the affricate, it only restricts it to some extent. But the main point is yet to come: The ratio between the duration of the closure phase and the duration of the whole affricate (the T/TS ratio) changes as follows: in unrestricted (nonflanked) cases, this ratio grows from 0.39 to 0.54 in geminates, whereas in restricted (flanked) cases, that is, those exhibiting degemination effects, it grows from 0.26 to 0.33 . The latter change of ratio appears to be small, but it is significant.

Pycha $(2010,147)$ finally comes to the following conclusion:

\begin{abstract}
Affricate gemination in Hungarian has two distinct correlates, or 'signatures': an overall duration increase, which we can refer to as the degree of lengthening, and an increase in T/TS ratio, which we can refer to as the type of lengthening. On this view, there is indeed something special about affricates placed in restricted gemination positions, because these affricates can potentially satisfy the demands of the restriction and of gemination at the same time. [...] The current study shows that for the most part this is exactly what happens, although small increases in overall durations are still evident. In other words, changes in affricate structure reflect not random variation, but the principled use of an alternative signature for gemination, namely an increase in T/TS ratio The finding that different correlates of lengthening can occur largely independently of one another [...] suggests that an accurate characterization of the phonetics-phonology interface requires focusing not on how cognate processes differ in degree, but how they differ in type.
\end{abstract}

What consequences emerge from all this with respect to our main topic, degemination? First, we could draw the radical conclusion that Siptár (2000)'s (autosegmental) approach to geminates, degemination, and consonant length in general, is totally misguided. But even if we do not to wish to go that far, we can by no means stick to the notion that, in forms involving -val/-vel (and in other similar forms), we have to do with the lack of gemination (rather than degemination). But then, why is it that, in cases traditionally seen as degemination, the consonant does, after all, get shorter (or does fail to get lengthened)?

\title{
3. The duration of consonant clusters and degemination
}

The key may be given by a glance at the duration of consonant clusters of various sizes $(\mathrm{CC}$, CCC, etc.) In Olaszy (2007), in a sample with 10.5 sounds/s rate of articulation, the mean duration of intervocalic consonants (VCV) turned out to be $92 \mathrm{~ms}$, and that of two-term intervocalic consonant clusters (VCCV) was $162 \mathrm{~ms}$ (rather than $184 \mathrm{~ms}$ that would be a simple doubling of the duration of single consonants). As we said above, citing Olaszy (2006), the mean length of geminates is $165 \%$ of that of singletons; now we can add that the mean length of two-term clusters is $176 \%$ of that of single consonants. Of course, average data always conceal individual differences, but the similarity of the two percentages is nevertheless striking. Consider CCC clusters now. Their mean duration in Olaszy (2007)'s material is $186 \mathrm{~ms}$, that is, a mere $15 \%$ longer than that of CC clusters - but almost exactly the double of the duration of consonants in VCV position. This easily leads to the hypothesis that the phenomenon we thought was a degemination effect so far is nothing but a natural compression of CCC clusters. In other words, a cluster of singleton + geminate (in any order) may just seem to be a cluster of singleton + singleton, given that the total length of the cluster is roughly the same (or at least far from being 3:2). Before we give a more accurate formulation of that hypothesis, let us note that this tendency of relative compression does not 
carry over to CCCC clusters: if it did, these would have to be about $200 \mathrm{~ms}$ long - but in reality they are $234 \mathrm{~ms}$. Of course, this figure is still far lower than the duration of single consonants taken four times ( $368 \mathrm{~ms}$ ) or even just three times $(276 \mathrm{~ms})$; but it is $125 \%$ of the mean length of CC clusters and 254\% of that of intervocalic single C's. Olaszy $(2007,203)$ suggests that the reason why the tendency of compression does not carry over to CCCC clusters is that "the articulation mechanism does not easily cope with sequences of four consonants. While for CCC clusters overall articulation becomes lenited, for CCCC clusters it undergoes fortition." At any rate, further exploration of four-term clusters (and CC + geminate or geminate $+\mathrm{CC}$ clusters) could yield interesting insights; but for the time being, let us stick to CCC clusters and left/right-flanked geminates. Let us formulate the following hypothesis:

(8) The familiar degemination effects are not geminate-specific at all; rather, they result from the general phonetic compression of CCC clusters, irrespective of whether they involve underlying or derived, true or fake, and right- or left-flanked geminates.

\section{Method, material, and subjects}

In order to test the hypothesis in (8), we conducted the following experiment. We had our subjects read out six short passages. The consonant sequences under study and their phonological characteristics are summarised in Table 1. We analysed nine fake geminates, three derived true geminates and two underlying geminates, as well as ten CC, six CCC, and three CCCC control sequences.

Table 1. The consonant clusters analysed (see text further below for glosses)

\begin{tabular}{|c|c|c|c|}
\hline \multirow{2}{*}{$\frac{\text { Cluster }}{\int \# \int \mathrm{p}}$} & \multirow{2}{*}{$\begin{array}{l}\text { Carrier word/phrase } \\
\text { édes spenótot; sós spenótot }\end{array}$} & \multicolumn{2}{|c|}{ Characteristics } \\
\hline & & fake & right-flanked \\
\hline $\mathrm{r} \int \# \int \mathrm{p}$ & nyers spenótot & fake & right/left-flanked \\
\hline $\mathrm{tt} \# \int \mathrm{p}$ & fött spenótot & control & $\mathrm{CCCC}$ \\
\hline $\int \mathrm{p}, \int \# \mathrm{p}$ & a spenótot; és persze & control & $\mathrm{CC}$ \\
\hline rpp & szörppel & true & left-flanked \\
\hline rpt, rpr & szörptöl; szörpre & control & $\mathrm{CCC}$ \\
\hline $\mathrm{rp}$ & szörpöt & control & $\mathrm{CC}$ \\
\hline $\mathrm{ntt}$ & ponttól & fake & left-flanked \\
\hline$n t t$ & ponttal & true & left-flanked \\
\hline nt & pontot & control & $\mathrm{CC}$ \\
\hline ntr, nts & pontra; pontszám & control & $\mathrm{CCC}$ \\
\hline $\operatorname{lm}(\#) \mathrm{m}$ & filmmúzeumban, film még & fake & left-flanked \\
\hline $\operatorname{lmm}$ & filmmel & true & left-flanked \\
\hline $\operatorname{lm}$ & filmet & control & $\mathrm{CC}$ \\
\hline $\operatorname{lms}$ & filmszemle & control & $\mathrm{CCC}$ \\
\hline lmkl & filmklub & control & $\mathrm{CCCC}$ \\
\hline s\#st & olasz sztárok & fake & right-flanked \\
\hline $\operatorname{ss}(\#) \mathrm{t}$ & össztársadalmi, klassz társaságba & underlying & right-flanked \\
\hline st & esztergályosok, olvasztárok & control & $\mathrm{CC}$ \\
\hline gst & világsztár & control & $\mathrm{CCC}$ \\
\hline $\mathrm{rt \# st}$ & mert sztárnak & control & $\mathrm{CCCC}$ \\
\hline nk\#k & magunk között, tolnánk ki & fake & left-flanked \\
\hline nkk & magunkkal & true & left-flanked \\
\hline nk & senki, minket, magunk $\|$ & control & $\mathrm{CC}$ \\
\hline
\end{tabular}

The test passages were read three times by ten university students from Budapest, 5 men and 5 women, aged between 19 and 24. The subjects' hearing and speech production was normal. In the case of one female subject, only two readings were such that we could use them in our study. With all the other subjects, the actual number of tokens we analysed depended on 
various alternative pronunciations (see below) and some reading errors that had to be excluded.

Recordings were made in a sound proof room, at 16 bit quantisation level and 22,100 $\mathrm{Hz}$ sampling rate, by the speech recording apparatus of the Praat 5.3 software (Boersma \& Weenink 2012). The analyses were likewise made in the Praat software. We have labelled the full duration of the clusters under study and that of the target consonants.

We located segment boundaries at VC and CV boundaries, as well as in clusters involving sonorants, at the offset and onset of the second formant of the vowel; in cases where approximants were involved, at the midpoint of the sound transition; and in cases involving fricatives, at the null transition closest to the beginning/end of the noise (Fig. 1). In consonant clusters involving obstruents, we marked the beginning and end of fricative noise and the end of burst, respectively, as segment boundaries. In cases where continuous fricative airflow was observable during the closure phase, we determined the segment boundary on the basis of the characteristic frequency and formant structure of the previous fricative. If, in sequences of two plosives, the burst of the first was not attestable, we did not mark them as two separate speech sounds.

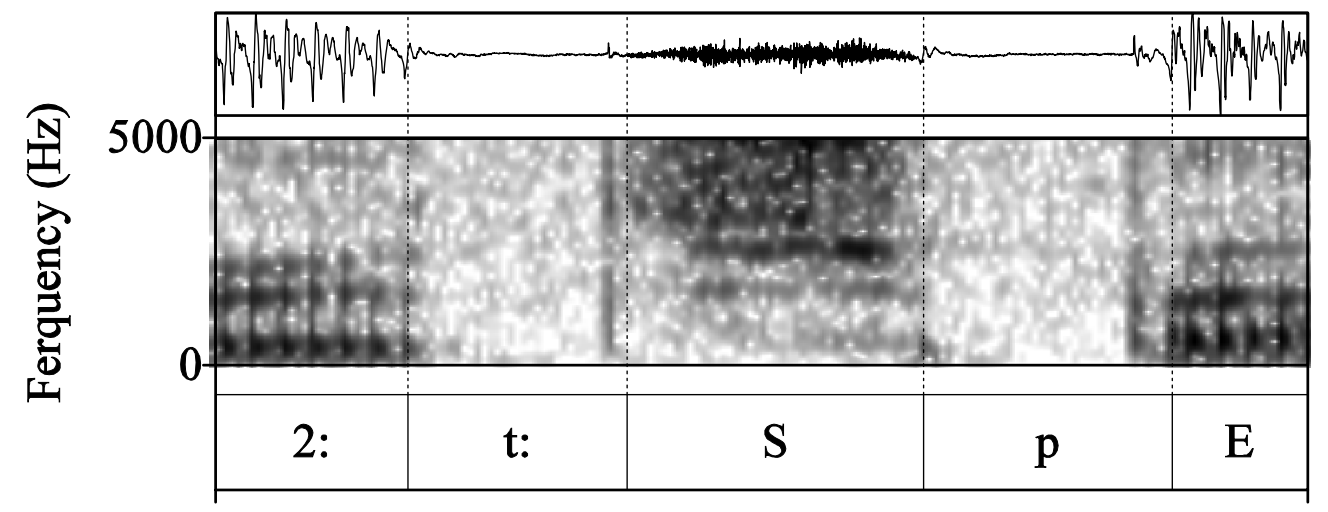

8.434

8.763

Time (s)

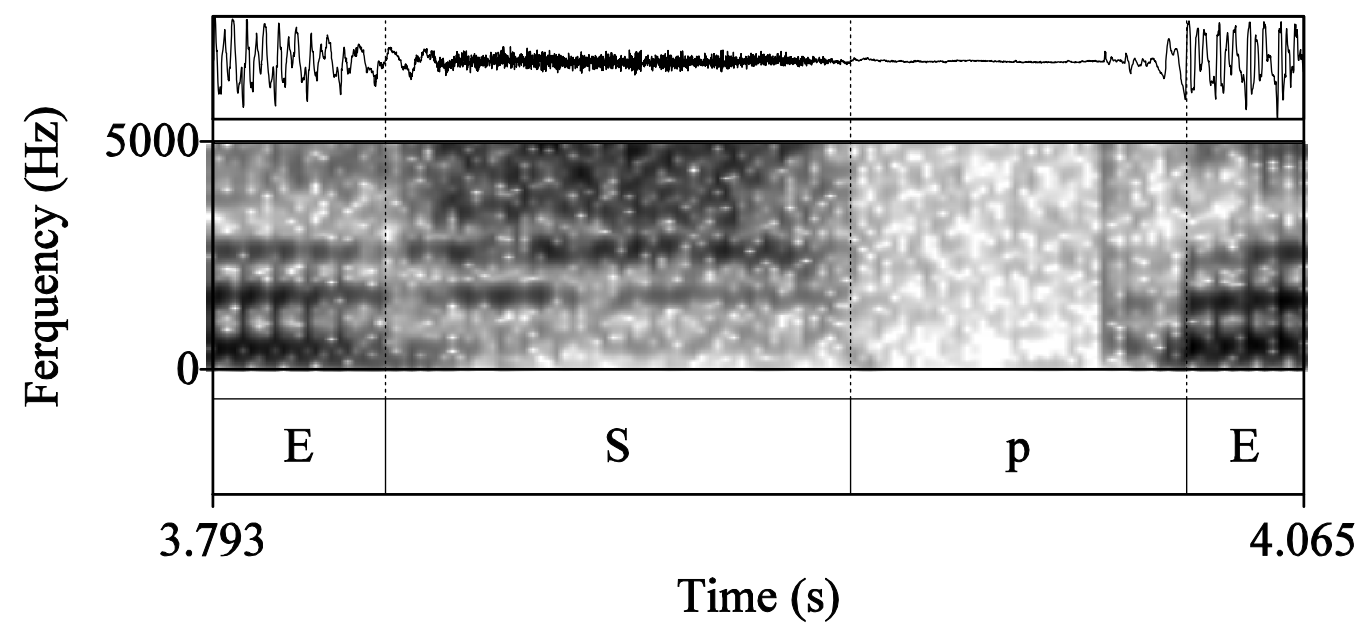

Figure 1

Examples of the segmentation process. Top panel: part of fött spenótot 'cooked spinch-acc'; bottom panel: part of édes spenótot 'sweet spinach-acc'

Statistical analyses were performed by the SPSS 19.0 software. We compared the absolute duration of the target sound using repeated measures and Bonferroni post hoc tests (Sajtos \& Mitev 2007, 176). 


\section{Results}

The sequences we studied exhibited quite some phonetic variation, of course. As expected, /1/ and /r/ were deleted in certain cases (e.g. Siptár \& Törkenczy 2000; Szende 2011), and /r/ was realised in a number of phonetic shapes (e.g. Gósy 2008). /r/ often failed to be pronounced before a consonant. In / $/ \mathrm{m} /$ clusters, /1/ often failed to be pronounced or it was produced in overlap with the $/ \mathrm{m} /$ (on the relative timing of articulatory gestures, e.g. Hoole 1999). Some instances of /st/ were not segmentable into fricative + closure + burst: the fricative portion was in some cases immediately followed by burst (e.g. Gráczi 2008). The velar nasal was sometimes unpronounced too, represented by nasalisation on the preceding vowel. ${ }^{22} \mathrm{In} / \mathrm{pt} /$ clusters, the first plosive was sometimes unexploded (see e.g. Elekfi 1992). The word mert 'because' occurred in a number of lenited forms (mer, me), involving the deletion of one or two consonants (see e.g. Lanstyák 2009). The proportions and significance of such variability will be discussed in the individual analyses.

The results will be summarised separately for each target consonant, given that their individual phonetic properties and the resulting specific characteristics of the cluster may also affect the way they are implemented.

\section{1. (C)/J(:)p/ clusters}

We had to exclude four tokens from the analysis, thus we analysed a total of 57 right-flanked geminates (/f:p/), as well as $58 / \int \mathrm{p} /, 28 / \mathrm{t}: \int \mathrm{p} /$, and $27 / \mathrm{r} \int \mathrm{p} / \mathrm{p}$ clusters. Of these, the acoustic reflex of $/ \mathrm{t}$ :/ was missing in eight cases (13.8\%), and that of $/ \mathrm{r} /$ in 21 cases $(77.8 \%)$.

The mean duration of the realisations of $/ \int: /$ was $86 \pm 24 \mathrm{~ms}$ and $99 \pm 33 \mathrm{~ms}$ in the two right-flanked geminates (sós spenótot 'salted spinach-acc', édes spenótot 'sweet spinachacc'), and $102 \pm 39$ in the right/left-flanked geminate (nyers spenótot 'raw spinach-acc'). The mean duration of $/ \mathrm{f} /$ realisations was $71 \pm 16 \mathrm{~ms}$ and $85 \pm 18 \mathrm{~ms}$ long in the two CC clusters (és persze 'and of course', a spenótot 'the spinach-acc') and $92 \pm 27 \mathrm{~ms}$ in the CCCC one (fótt spenótot 'cooked spinach-acc') (Fig. 2). The duration of $/ \int: /$ realisations in the right/leftflanked geminate was longer or appeared in the higher region of the right-flanked geminates with $60 \%$ of the speakers. The duration of $/ \mathrm{s} /$ realisations in the CCCC clusters was longer in the pronunciation of 6 speakers than in the $\mathrm{CC}$ clusters, and $70 \%$ of the participants pronounced longer $/ \mathrm{J} /$ in the cluster across a word boundary.

\footnotetext{
${ }^{22}$ Nasal deletion is usually claimed to be restricted to the environment of a following continuant, e.g. in Siptár \& Törkenczy (2000); however, in our acoustic analyses it could also be seen to happen in the realisation of /nk/ clusters.
} 


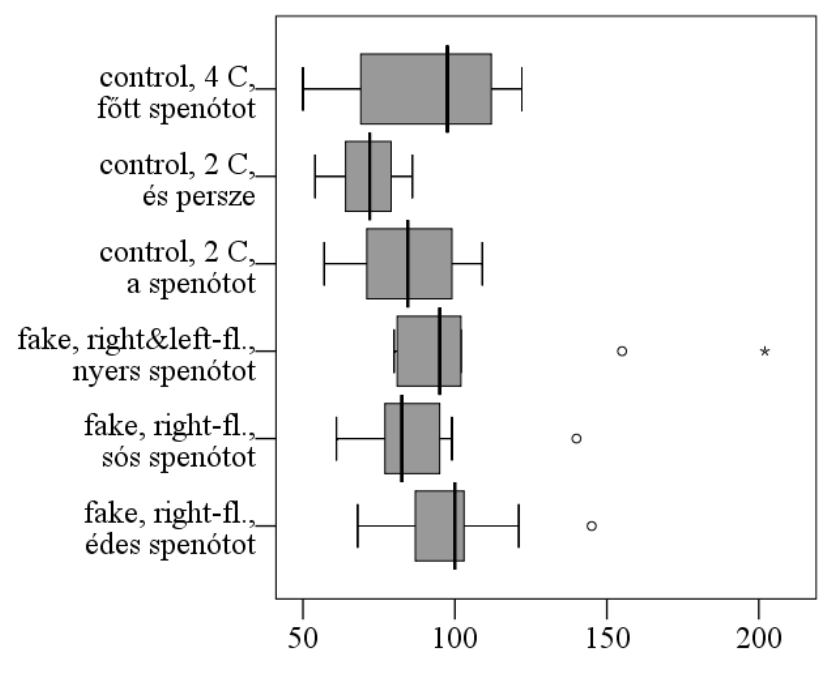

Figure 2

The duration of $/ \int(\mathrm{a}) /$ realisations

The duration of $/ \int(\mathrm{s}) /$ realisations in the right/left-flanked geminate was longer than or appeared in the higher region of the two CC control clusters with $80 \%$ of the speakers. This difference was statistically significant according to the repeated measures $[F(5,10)=6.104 ; p$ $\left.<0.001, \eta^{2}=0.404\right]$ and the Bonferroni test.

\section{2. (C)/nt(:)/ clusters}

We had to exclude 17 tokens from the analysis due to deletion $(34.5 \%)$ or unexpected realisations ([ts] or [s], 24.1\%).

The mean duration of $/ \mathrm{t}(\mathrm{:}) /$ was the shortest in the two CCC clusters (pontszám 'score': $39 \pm 11 \mathrm{~ms}$, pontra 'onto dot': $46 \pm 14 \mathrm{~ms}$ ) and the longest in the CC cluster (pontot 'dot-acc': $84 \pm 16 \mathrm{~ms}$ ). In the pronunciation of $90 \%$ of the participants, the duration of $/ \mathrm{t} /$ in the first two was shorter than in the third item (Fig. 3). The duration was shorter in the true geminate (ponttal 'with dot': $66 \pm 14 \mathrm{~ms}$ ) than in the fake one (ponttól 'from dot': $80 \pm 26 \mathrm{~ms}$ ). Analysing the results speaker by speaker, the latter was longer or appeared in the higher region of the former in the pronunciations of $60 \%$ of the participants, and they appeared in the same duration region in the other $40 \%$.

The duration of $/ \mathrm{t} /$ realisations in the true geminate was longer $(80 \%$ of the speakers) than - or appeared in the higher region (the other 2 speakers) of - that in the longer CCC control cluster, and was not longer than that in the $\mathrm{CC}$ control one (all speakers). The duration of $/ \mathrm{t} /$ in the fake geminate was longer than that in the CCC cluster in the case of all speakers.

These differences proved to be statistically significant by the repeated measures $\left(F(2.407,10)=46.441 ; p<0.001, \eta^{2}=0.838\right)$. According to the Bonferroni test, the duration of the $/ \mathrm{t} /$ realisations was the longest in the CC clusters, the shortest in the CCC ones, and was in the middle of this scale in the left-flanked fake and the true geminates. The difference of the latter two was not proven to be statistically significant. 


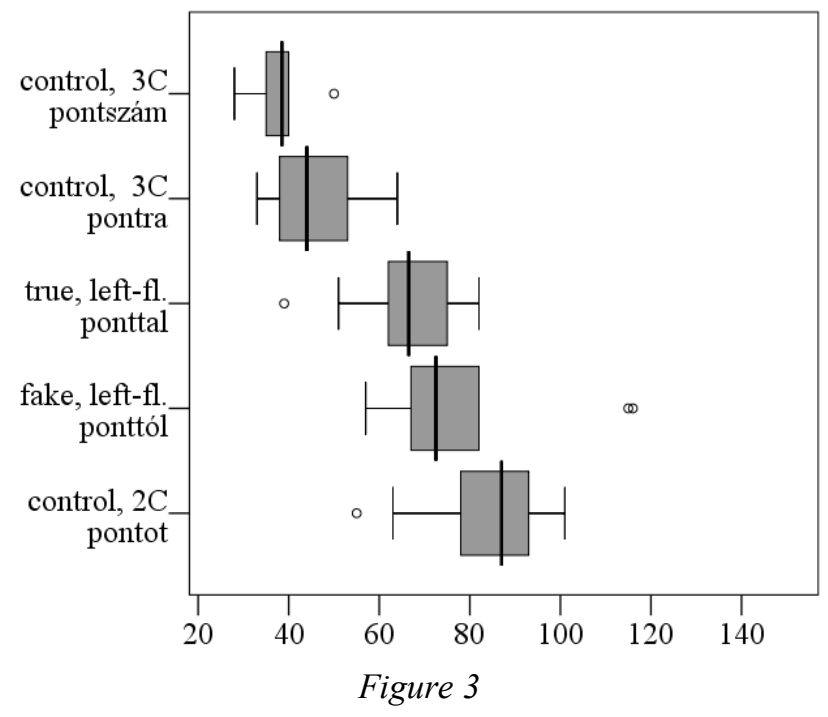

The duration of $/ \mathrm{t}(\mathrm{s}) /$ realisations

\section{3. $/ \mathbf{r p}(\mathfrak{a}) /(\mathrm{C})$ clusters}

The realisations of $/ \mathrm{p}(\mathrm{i}) /$ were analysed in a true geminate and in three control clusters. Some of these had to be excluded due to the lack of detectable burst of the consonant $(37.9 \% \mathrm{of} / \mathrm{pt} /$, $3.4 \%$ of $/ \mathrm{rpr} /)$ and misreading (3.4\% of szörppel 'with syrup'). /r/ was deleted 49 times (/rp/: $10.3 \%$, /rp:/: $75.9 \%, / \mathrm{rpr} /:$ 65.5\%, /rpt/: 17.2\%) These cases are included in the analysis; however, the duration of $/ \mathrm{p} /$ may be affected by the deletion.

The realisations of $/ \mathrm{p}(\mathrm{i}) /$ (Fig. 4) showed similar mean duration patterns to those of the realisations of $/ \mathrm{t}(\mathrm{s}) /$; however, the results are not as straightforward. The target consonant was the longest in the CC cluster (szörpöt 'syrup-acc': 100土14 ms) and the shortest in the CCC ones (szörptöl 'from syrup': $79 \pm 18 \mathrm{~ms}$ and szörpre 'onto syrup': $82 \pm 33 \mathrm{~ms}$ ). The realisations in the left-flanked true geminate appeared in the middle of this scale (szörppel 'with syrup': $93 \pm 14 \mathrm{~ms})$. The duration of $/ \mathrm{p} /$ in the CC control cluster was longer than that in the two CCC ones with $70 \%$ of the speakers. The results of the repeated measures $[F(3,10)=4.529 ; p=$ $\left.0.012, \eta^{2}=0.361\right]$ and the Bonferroni test proved only the difference between the CC clusters and one of the CCC ones to be significant.

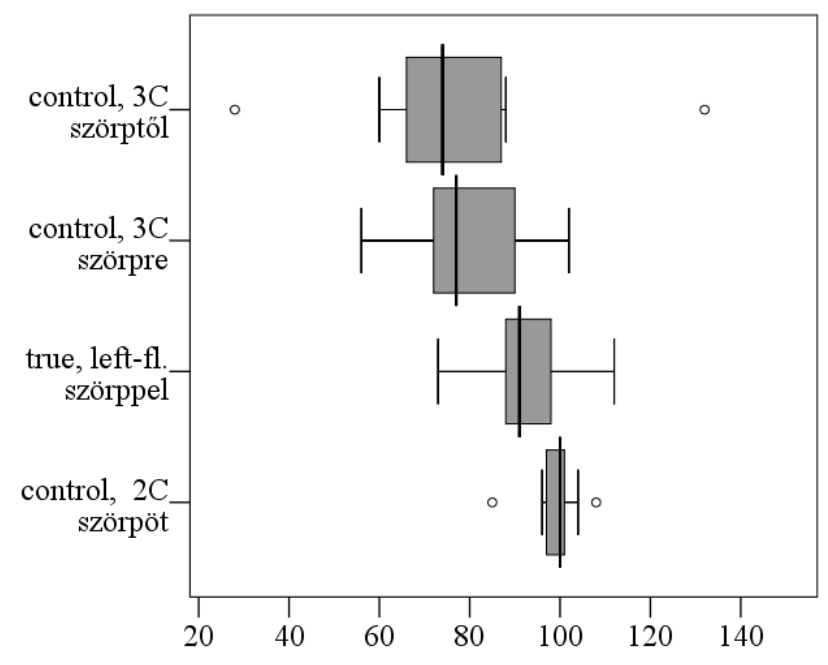

Figure 4

The duration of $/ \mathrm{p}(\mathrm{:}) /$ realisations 


\section{4. $/ \mathrm{Im}(\mathrm{i}) /(\mathrm{C})$ clusters}

We had to exclude 8 cases in the analysis of $/ \mathrm{m} /$ realisations. In some cases the speaker inserted a pause between the words in the phrase film még 'film yet' $(27.6 \%)$, and the realisation of $/ 1 /$ was unquestionably measurable in only a few cases of all words and phrases.

The mean duration of $/ \mathrm{m} /$ in the clusters with fake geminates was $90 \pm 19 \mathrm{~ms}$ and $97 \pm 26$ $\mathrm{ms}$, while in the cluster with a true geminate (dokumentumfilmmel 'with a documentary') it was $79 \pm 14 \mathrm{~ms}$ (Fig. 5.). The mean duration of $/ \mathrm{m} /$ in the control clusters showed a different pattern from those of the previous consonants. The three-consonant sequence (filmszemle 'film festival') showed a similar value $(70 \pm 16 \mathrm{~ms})$ to the two-consonant cluster (játékfilmet 'feature film-acc': $67 \pm 10 \mathrm{~ms}$ ). The shortest mean duration was measured in the CCCC cluster (filmklub 'movie fan club': $56 \pm 16 \mathrm{~ms}$ ). In the true geminate, the duration was shorter than that in the fake ones with $60 \%$ of the speakers, and shorter than at least in one of those with a further $30 \%$ of the speakers. The duration of $/ \mathrm{m} /$ in the geminates appeared or started in $80 \%$ of the speakers in the higher region that was covered by the controls. The repeated measures proved the significance of the differences of durations $\left[F(5,10)=5.326 ; p=0.001, \eta^{2}=\right.$ 0.372); however, only one of the fake geminates (filmmúzeumban 'in the cinema museum') proved to be longer than the realisations of $/ \mathrm{m} /$ in the $\mathrm{CC}$ and the $\mathrm{CCCC}$ clusters, and that in the true geminate to be longer than in the CCCC case.

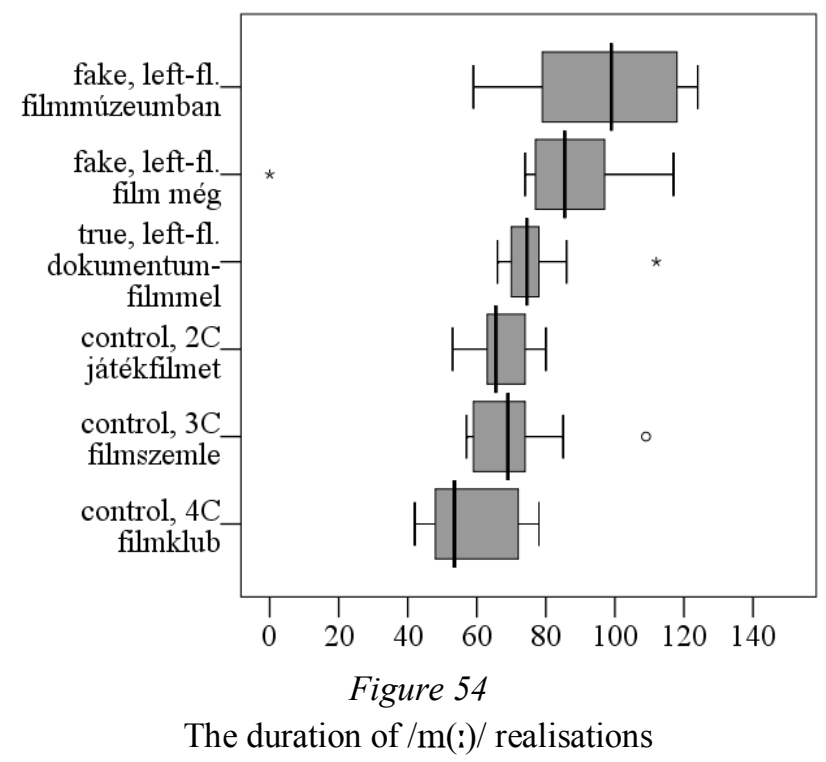

\section{5. $/ \mathrm{s}(\mathrm{I}) /(\mathrm{C})$ clusters}

We had to exclude two pronunciations of $/ \mathrm{s}(\mathrm{i}) \mathrm{t} /$ due to disfluency phenomena, four due to pause, and fourteen due to the realisation of $/ \mathrm{s} /$ and $/ \mathrm{t} /$ as one consonant. The first and the last consonant of the phase mert sztárnak 'because for a star' rarely appeared in the realisations.

The mean duration of /s(:)/ realisations (Fig. 6) was longer in the fake geminates (olasz sztárok 'Italian stars': $107 \pm 16 \mathrm{~ms}$ ) than in the true (underlying) ones (össztársadalmi 'involving the whole society': $71 \pm 21 \mathrm{~ms}$, klassz társaságba 'into a smashing company': $78 \pm 19 \mathrm{~ms}$ ). This value was rather different in the two CC clusters (esztergályos 'lathe operator': $72 \pm 28 \mathrm{~ms}$, olvasztárok 'furnacemen': $93 \pm 20 \mathrm{~ms}$ ). The CCC cluster showed similar results to the shorter CC one (világsztár 'world star': $72 \pm 26 \mathrm{~ms}$ ), while the longest values of the control clusters were measured in the CCCC item (mert sztárnak 'because for a star': $107 \pm 16 \mathrm{~ms})$. The duration of $/ \mathrm{s} /$ in the fake geminate was longer than or appeared in the higher region of that in the underlying ones with all speakers. The duration in one of the 
underlying geminates (klassz társaságba) was longer than in the other one (össztársadalmi) in the rendering of $60 \%$ of the speakers. The duration of /s/ in olvasztárok was longer than that in esztergályos (CC control clusters) with $80 \%$ of the speakers. The duration of $/ \mathrm{s} /$ realisations in the CCCC cluster was never the shortest, and that in the CCC one was also longer in most speakers' renderings than the shorter CC control cluster.

The differences among the durations measured in the clusters proved to be statistically significant (repeated measures: $F(6,10)=13.750 ; p<0.001, \eta^{2}=0.604$ ). According to the Bonferroni test, the duration differences of $/ \mathrm{s} /$ realisations were significant between the two $\mathrm{CC}$ clusters, between that in both $\mathrm{CC}$ clusters and in one of the underlying geminates (klassz társaságba) and in the fake one, and between that in the fake geminate and the CCC cluster.

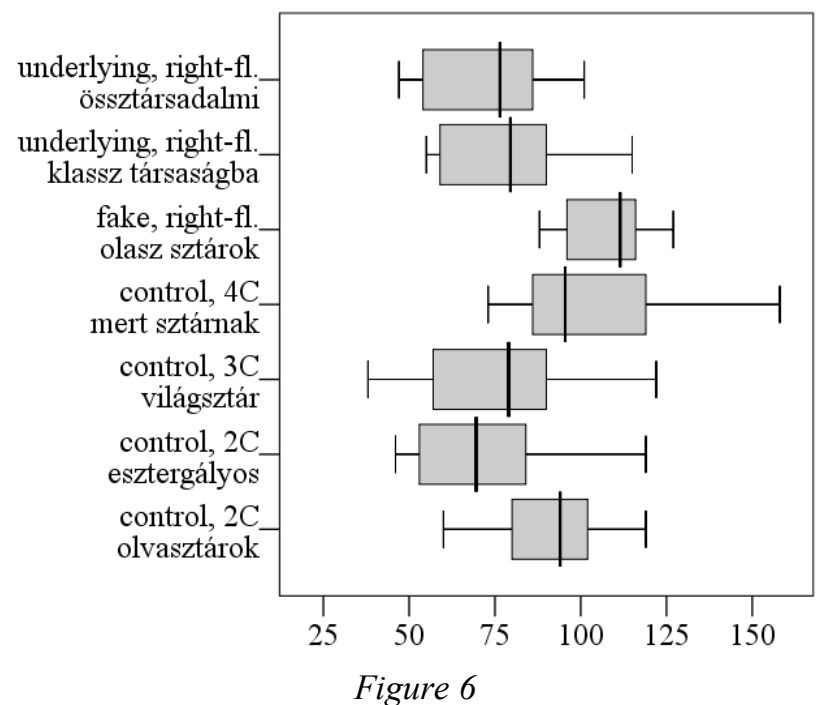

The duration of $/ \mathrm{s}(:) /$ realisations

\section{6. $/ \mathbf{n k}(\mathrm{i}) /(\mathrm{C})$ clusters}

One realisation of a CC control cluster had to be eliminated due to misreading $(3.4 \%)$. In some pronunciations, the cluster was realised with $/ \mathrm{k} /$-deletion.

The mean duration of $/ \mathrm{k}(:) /$ realisations (Fig. 7) was similar in one of the fake geminates and in the true geminate (magunk között 'among ourselves', magunkkal 'with ourselves': $87 \pm 21 \mathrm{~ms}$ ), while it was somewhat longer in the other fake geminate (tolnánk ki 'we would push out': $110 \pm 23 \mathrm{~ms})$. The duration of the $/ \mathrm{k} /$ realisations was quite different in the three CC clusters $(66 \pm 15 \mathrm{~ms}, 103 \pm 16 \mathrm{~ms}, 118 \pm 47 \mathrm{~ms})$. The duration of $/ \mathrm{k} /$ in the longer fake geminate appeared in the highest region of all data with $80 \%$ of the speakers. The shortest duration in the geminates was longer than that in the shortest controls in all speakers' pronunciation. The duration of $/ \mathrm{k} /$ in senki 'nobody' was longer than that in minket 'us' in all speakers' pronunciation. The duration in one of the fake geminates (tolnánk ki) was longer than that in the other two geminates in the case of $80 \%$ of the speakers.

The differences were significant [repeated measures: $F(5,10)=12.096 ; p<0.001$, $\left.\eta^{2}=0.573\right]$. According to the Bonferroni test, the duration of the $/ \mathrm{k} /$ realisations was the shortest in the word minket, and that in the true geminate was shorter than in tolnánk ki and senki, while it was longer than that in minket. Also the duration of the analysed consonant was longer in both fake geminates than in one of the CC clusters (minket). 


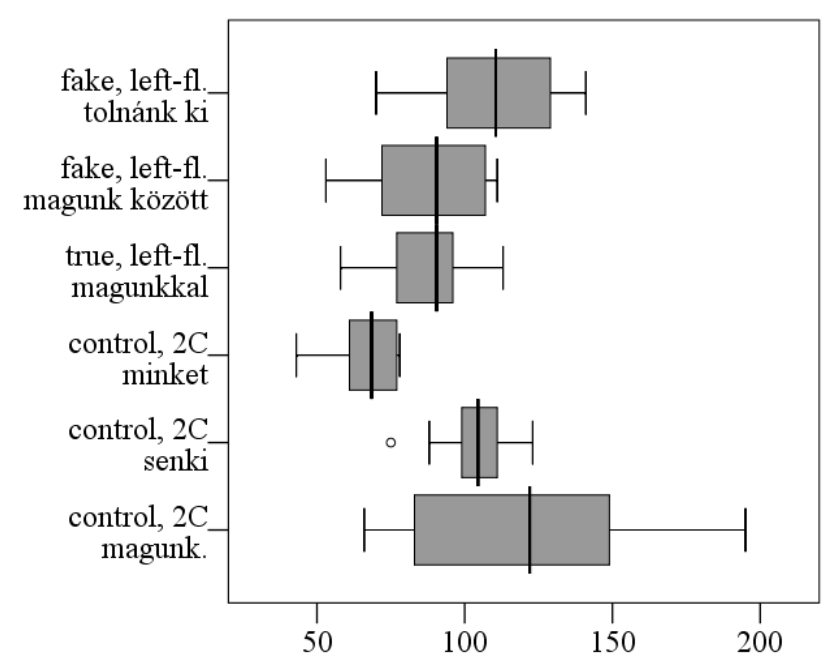

Figure 7

The duration of $/ \mathrm{k}(\mathrm{:}) /$ realisations

\section{Summary}

In this paper, we have looked at the issue of whether the durational behaviour of geminates flanked by a further consonant in Hungarian should be seen as a matter of (phonological) degemination or whether such sequences simply exhibit the (phonetic) temporal patterns characteristic of triliteral consonant clusters in general. Furthermore, we wanted to see if all this depends on the type of geminate involved.

The experiment we conducted involved six different phonemes. We studied both simple and complex target sounds; all types of geminates occurred in the corpus. Some of the results we obtained turned out to confirm our initial hypothesis while others contradicted it.

For instance, the data of suffixed forms and compounds involving szörp 'syrup' and pont 'dot' appeared to provide evidence against degemination, whereas the items össztársadalmi 'involving the whole society' and klassz társaságba 'into a smashing company' appeared to support the idea of degemination (of underlying geminates). In what follows, we review the results of implementations of these items in which all relevant phonemes were represented by distinct speech sounds, in order to exclude from this summary at least one reason for the variability mentioned earlier.

The mean length of the whole cluster in szörpöt 'syrup-acc' was $140 \mathrm{~ms}$, in szörptöl 'from syrup' it was $142 \mathrm{~ms}$, and in szörppel 'with syrup' it was a mere $123 \mathrm{~ms}$; the flanking consonant ([r]) was shortened in both of the latter cases (to 22 and $28 \mathrm{~ms}$, respectively) as compared to its duration in the $\mathrm{CC}$ cluster $(43 \mathrm{~ms})$. This suggests that what happens in szörppel is not degemination in the traditional sense but a temporal "compression" of the cluster just like in CCC clusters in general (Fig. 8). 


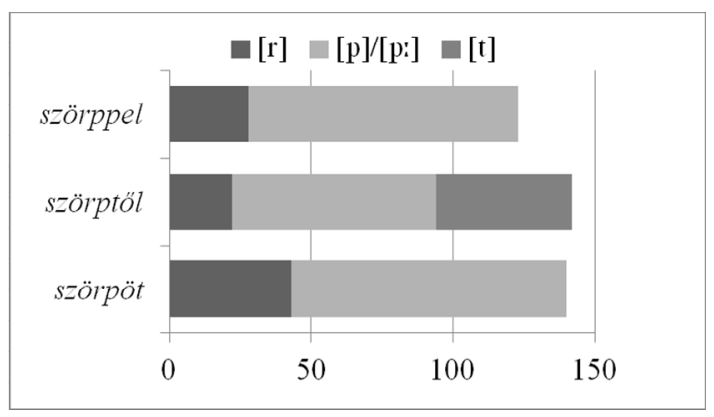

Figure 8

Mean length (ms) of the consonants of the cluster in instances of suffixed forms of szörp 'syrup' in which both/all three consonants were actually pronounced

Although the identical durations of the fake geminate in ponttól 'from dot' and the [t] in pontot 'dot-acc' seem to tilt the balance toward a degemination analysis, the fact that the length of $[\mathrm{n}]$ in ponttól is less than half of that of the [t] speaks against the degemination analysis (even if the [t] is also longer than the [n] in pontot; see Fig. 9).

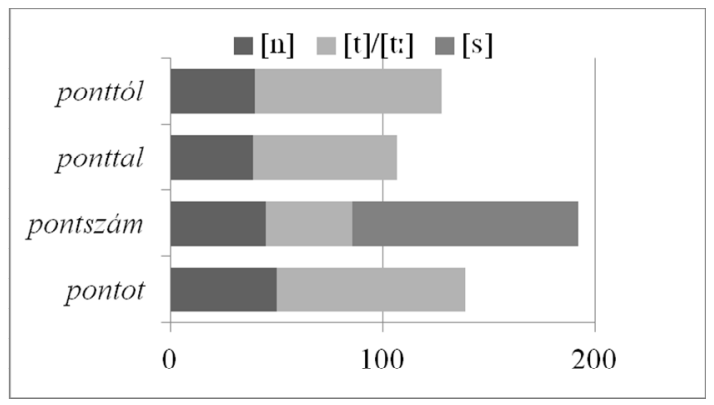

Figure 9

Mean length (ms) of the consonants of the cluster in instances of suffixed/compounded forms of pont 'dot' in which both/all three consonants were actually pronounced

On the other hand, in the case of our results concerning the shortening of underlying geminates in items involving [s:] the possibility of actual degemination does arise, given that the duration of the flanked true geminates was typically shorter than what we measured for fake geminates $(85 \mathrm{~ms}$ and $81 \mathrm{~ms}$ vs. $113 \mathrm{~ms}$ ). However, due to the large discrepancies we found in the data of the control sequences, this type calls for further investigation before we can say anything more substantial about it.

Some variability of the clusters analysed may be due to other characteristics of the clusters, factors like the syllable position or the articulatory features of the target consonants or of the other consonants in the clusters (see e.g. Byrd 1996). For example, in the case of clusters involving pont 'dot', all consonants were homorganic and no overlapping articulation was possible, while in those involving szörp 'syrup', the consonants were not always homorganic, and the $/ \mathrm{r} / \mathrm{was}$ often deleted (not in the realizations analysed above). These features must be controlled for in a more detailed analysis. However, taking the results of all clusters together, the type of the geminate seems to be a most relevant factor with respect to the duration of the "degeminated" consonant.

The rest of the data we have analysed show that in those cases, due to the large variability we referred to earlier, additional considerations and a larger material are to be involved in their investigation.

\section{Conclusion}

The initial hypothesis of this study was that the familiar degemination effects may not be geminate-specific at all; rather, they may be results of a phonetic compression characteristic 
of CCC clusters in general, irrespective of whether we have to do with right- or left-flanked geminates and whether they are of the true or the fake kind. As a final conclusion, we can suggest that, although our hypothesis has failed to be confirmed in its simple and straightforward form, what nevertheless revealed itself was that the conventional treatment of alleged cases of degemination in categorical or phonological terms is untenable and the real explanation of these phenomena could be found somewhere in the direction we were trying to propose in our hypothesis. At any rate, numerous further experiments, and analyses conducted on far larger materials, would be necessary for us to really see clearly in this matter.

\section{References}

Beke, András and Dorottya Gyarmathy. 2010. Zöngétlen résmássalhangzók akusztikai szerkezete [The acoustic structure of voiceless fricatives]. Beszédkutatás 2010. 57-75.

Boersma, Paul and David Weenink. 2012. Praat: doing phonetics by computer. Software package, www.praat.org

Browman, Catherine P. and Louis M. Goldstein. 1992. Articulatory phonology: An overview. Phonetica 49. 155-180.

Byrd, Dani. 1996. Influences on articulatory timing in consonant sequences. Journal of Phonetics 24. 209-244.

Clements, George N. 1985. The geometry of phonological features. Phonology Yearbook 2. $225-252$.

Davis, Stuart. 2011. Geminates. In Marc van Oostendorp, Colin Ewen, Elizabeth Hume and Keren Rice (eds.) The Blackwell companion to phonology Vol. II. Oxford: WileyBlackwell. 1597-1621.

Delattre, Pierre. 1971. Consonant gemination in four languages: An acoustic, perceptual, and radiographic study. International Review of Applied Linguistics in Language Teaching 9. 31-52; 97-113.

Dressler, Wolfgang U. and Péter Siptár. 1989. Towards a natural phonology of Hungarian. Acta Linguistica Hungarica 39. 29-51.

Elekfi, László. 1992. A magyar hangkapcsolódások fonetikai és fonológiai szabályai [Phonetic and phonological regularities in Hungarian sound sequences]. Budapest: Research Institute for Linguistics of the Hungarian Academy of Sciences.

Gósy, Mária. 2008. R hangok: kiejtés, hangzás, funkció [R sounds: production, acoustic pattern, and function]. Magyar Nyelv 132. 1-17.

Gráczi, Tekla Etelka. 2008. Alveoláris spiránsok akusztikai fonetikai vizsgálata [An acoustic phonetic investigation of alveolar fricatives]. Beszédkutatás 2008. 33-51.

Ham, William H. 2001. Phonetic and phonological aspects of geminate timing. New York: Routledge.

Hoole, Philip. 1999. Coarticulatory investigations of the devoicing gesture. In Hardcastle, William J. and Nigel Hewlett (eds.) Coarticulation: Theories, data and techniques. Cambridge: Cambridge University Press. 107-121.

Kovács, Magdolna. 2002. Az affrikáták időszerkezetéről [On the temporal structure of affricates]. In László Hunyadi (ed.) Kísérleti fonetika, laboratóriumi fonológia [Experimerntal phonetics and laboratory phonology]. Debrecen: Debreceni Egyetem Kossuth Könyvkiadója. 39-54.

Lanstyák, István. 2009. A magyar beszélt nyelv sajátosságai [The characteristics of spoken Hungarian]. Bratislava: Stimul.

Leben, William R. 1973. Suprasegmental phonology. Ph.D. dissertation, MIT.

Lehiste, Ilse, Katherine Morton and Marcel Tatham. 1973. An instrumental study of consonant gemination. Journal of Phonetics 1. 131-148. 
Local, John. 1992. Modelling assimilation in nonsegmental, rule-free synthesis. In Gerard G. Docherty and Robert Ladd (eds.) Papers in laboratory phonology II. Gesture, segment, prosody. Cambridge: Cambridge University Press. 190-223.

Nádasdy, Ádám. 1989. The exact domain of consonant degemination in Hungarian. Hungarian Papers in Phonetics 21. 104-107.

Obendorfer, Rudolf. 1975. The ambiguous status of Hungarian long consonants. Lingua 36. $325-336$.

Oh, Grace E. and Melissa A. Redford. 2012. The production and representation of fake geminates in English. Journal of Phonetics 40. 82-91.

Olaszy, Gábor. 2006. Hangidőtartamok és időszerkezeti elemek a magyar beszédben [Sound durations and temporal patterns in Hungarian speech]. Budapest: Akadémiai Kiadó.

Olaszy, Gábor. 2007. Mássalhangzó-kapcsolódások a magyar beszédben [Consonant clusters in Hungarian speech]. Budapest: Tinta Könyvkiadó.

Pickett, Emily R., Sheila E. Blumstein and Martha W. Burton. 1999. Effects of speaking rate on the singleton/geminate consonant contrast in Italian. Phonetica 56. 135-157.

Polgárdi, Krisztina. 2008. Geminates and degemination in Hungarian: A loose CV analysis. In Christopher Piñón and Szilárd Szentgyörgyi (eds.) Approaches to Hungarian 10. Papers from the Veszprém conference. Budapest: Akadémiai Kiadó. 127-146.

Port, Robert F. and Adam P. Leary. 2005. Against formal phonology. Language 81. 927-964.

Pycha, Anne. 2008. Morphological sources of phonological length. Ph.D. dissertation, University of California, Berkeley.

Pycha, Anne. 2009. Lengthened affricates as a test case for the phonetics-phonology interface. Journal of the International Phonetic Association 39. 1-31.

Pycha, Anne. 2010. A test case for the phonetics-phonology interface: gemination restrictions in Hungarian. Phonology 27. 119-152.

Ringen, Catherine O. and Robert M. Vago. 2011. Geminates: heavy or long? In Charles E. Cairns and Eric Raimy (eds.) Handbook of the syllable. Leiden: Brill. 155-169.

Sajtos, László and Ariel Mitev. 2007. Kutatási és adatelemzési kézikönyv. [Handbook of research and data analysis]. Budapest: Alinea Kiadó.

Siptár, Péter. 2000. Degemination in Hungarian. In Varga, László (ed.) The Even Yearbook 4. ELTE SEAS Working Papers in Linguistics. Budapest: School of English and American Studies, Eötvös Loránd University. 107-115.

Siptár, Péter and Miklós Törkenczy. 2000. The phonology of Hungarian. Oxford: Clarendon Press / Oxford University Press.

Stiebels, Barbara and Dieter Wunderlich 1999. Second stems in Hungarian nouns. The Linguistic Review 16. 253-294.

Szende, Tamás. 2011. Változási tendenciák a mai magyar beszédben [Tendencies of change in present-day Hungarian speech]. Magyar Nyelvőr 135. 107-112.

Trón, Viktor and Péter Rebrus. 2005. Re-presenting the past: contrast and uniformity in Hungarian past tense suffixation. In Christopher Piñón and Péter Siptár (eds.) Approaches to Hungarian 9. Papers from the Düsseldorf Conference. Budapest: Akadémiai Kiadó. 305-327.

Vago, Robert M. 1980. The sound pattern of Hungarian. Washington: Georgetown University Press. 